\title{
Verification through Pollen Incompatibility Studies of Pedigrees of Sweet Cherry Cultivars from Vineland
}

\author{
Ghassem Tehrani ${ }^{1}$ and William Lay $^{2}$ \\ Horticultural Research Institute of Ontario, Vineland Station, Ont. LOR \\ 2E0 Canada
}

Additional index words. Prunus avium, incompatibility groups

Abstract. Pedigrees of Wit', 'Venus', 'Viscount', 'Vogue', and 'Viva' sweet cherry cultivars (Prunus avium L.) were confirmed with pollen-incompatibility studies. 'Hedelfingen', the maternal parent of the last four cultivars, was assigned previously to Incompatibility Group VII $\left(S_{4} S_{5}\right)$; however, it was shown that Vineland 'Hedelfingen' belongs to Group ' $O$ ' (Universal Donors) rather than VII. Thus, the parentage of the above cultivars, with the exception of 'Vic', is correct as reported when these cultivars were named. 'Vie' pedigree is incorrect and it belongs to Group ' $O$ ' rather than the previously assigned XIII. 'Valera' also belongs to Group ' $O$ ' and the existence of Group XIV $\left(S_{1} S_{5}\right)$, with 'Valera' as its only representative cultivar, could not be confirmed.

Sweet cherry breeding, an ongoing program at Vineland since 1915, has produced 11 cultivars: Victor, Velvet, and Vernon, (Dickson, 1948); Vista, Venus, and Vic (Dickson, 1958); Vega and Valera (Tehrani and Dickson, 1967); Viva (Tehrani and Dickson, 1973); Vogue (Tehrani and Dickson, 1974); and Viscount (Tehrani, 1984). Through pollen-incompatibility studies, the reported parentage of 'Vie', 'Venus', 'Vogue', 'Viva', and 'Viscount' has been disputed (Tehrani, 1984; Tehrani and Dickson, 1973, 1974; Way, 1968). Parentage of sweet cherry cultivars can be verified by comparing the $\mathrm{S}$-alleles of the hybrid relative to the alleles of the presumed parents used in a cross.

Received for publication 7 June 1990. The cost of publishing this paper was defrayed in part by the payment of page charges. Under postal regulations, this paper therefore must be hereby marked advertisement solely to indicate this fact.

${ }^{1}$ Research Scientist.

${ }^{2}$ Agricultural Technician.
The major commercial sweet cherry cultivars are self-incompatible. When the specific $\mathrm{S}$-allele present in the haploid pollen grain is the same as one of the alleles present in the somatic tissue of the receptor pistil, the two cultivars will be incompatible. In addition, certain groups of cross-incompatible cultivars will form a pollen-incompatibility group designated with specific S-alleles; e.g., incompatibility Group III $\left(\mathrm{S}_{3} \mathrm{~S}_{4}\right.$, which includes 'Bing', 'Emperor Francis', 'Napoleon' (Royal Ann), 'Star', and 'Vernon' (Knight, 1969).

A homomorphic, monofactorial, multiallelic gametophytic system controls the pollen-incompatibility among different sweet cherry cultivars (Crane and Brown, 1937; Crane and Lawrence, 1929). Brown (1955) identified six S-alleles among sweet cherry cultivars and assigned them the designations $\mathrm{S}_{1}$ to $\mathrm{S}_{6}$. The possible combinations of these genes could produce 15 pollen-incompatibility groups among the sweet cherry cultivars. Crane and Lawrence (1931) first recognized the existence of nine incompati- bility groups. This number was raised to 11 by 1937 (Crane and Brown, 1937) and to 12 by 1955 (Crane and Brown, 1955). By this time (Brown, 1955), the S-alleles in nine out of 12 groups were identified (Table 1). In 1968, a new Incompatibility Group XIII $\left(\mathrm{S}_{2} \mathrm{~S}_{4}\right)$, was reported by Way (1968). He also reported another Group XIV $\left(\mathrm{S}_{1} \mathrm{~S}_{5}\right)$ that was identified by Matthews. and cited later by Matthews and Dow (1976). In addition to 13 groups identified (Knight, 1969), there is also a Universal Donors group (Group ' $O$ ') that includes several cultivars that will successfully pollinize clones belonging to the 13 groups and will be reciprocally pollinized by them. The S-alleles of Group 'O' are not known.

The objectives of this study were to: a) determine the pollen-incompatibility group of cultivars of which pedigrees have been disputed; b) verify the reported parentage of the cultivars; and c) clarify the assignment of 'Valera' as the only representative of Incompatibility Group XIV, reported by Way (1968) and mentioned by Matthews and Dow (1976).

To determine the S-alleles of a cultivar, test crosses were made between Vineland cultivars with unknown and a series of cultivars with known S-alleles. Incompatible crosses normally produce between $1 \%$ to $3 \%$ of fruit set, whereas compatible crosses result in $\geq 5 \%$ set (Way, 1968). Based on compatible $(+)$ or incompatible $(-)$ reactions, the allelic combination of the cultivars in question is determined (Table 1).

The above technique was used to show that the pedigrees of 'Venus', 'Viscount', 'Vogue', and 'Viva' were not correct if 'Hedelfingen' is assumed to have the ' $\mathrm{S}_{4} \mathrm{~S}_{5}$ ' allelic combination (Tehrani, 1984; Tehrani and Dickson, 1973, 1974; Way, 1968). These cultivars have 'Hedelfingen' as maternal parent. This cultivar has been reported not to be a true cultivar (Crane and Lawrence, 1931; DeVries, 1968). A European clone of 'Hedelfingen' was assigned to Group VII $\left(\mathrm{S}_{4} \mathrm{~S}_{5}\right)$ by Knight (1969).

Employing the above procedures, the as- 
Table 1. Identification of S-alleles, incompatibility groups, and verification of pedigree of sweet cherry cultivars named and introduced from Vineland and 'Hedelfingen'.

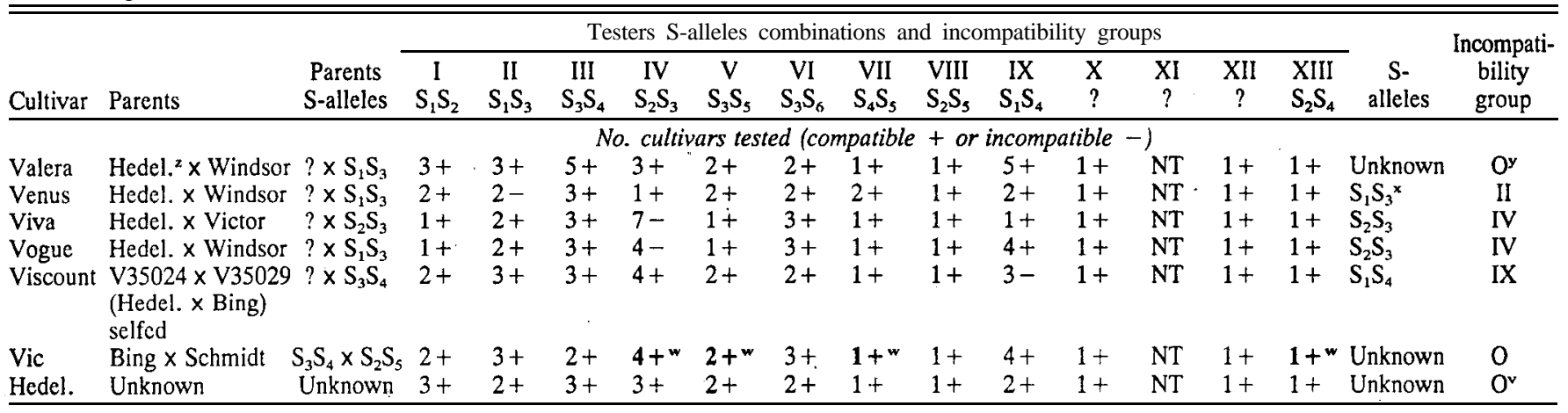

'Abbreviation for 'Hedelfingen'.

${ }^{y}$ Assigned to Incompatibility Group XIV $\left(\mathrm{S}_{1} \mathrm{~S}_{5}\right)$ by Matthews (Way, 1968).

${ }^{*}$ Reported by Matthews and Dow (1966).

"Boldface represents the four possible allelic combinations from the cross.

"Assigned to Incompatibility Group VII $\left(\mathrm{S}_{4} \mathrm{~S}_{5}\right)$ by Knight (1969).

${ }^{\mathrm{NT}}$ Pollen-incompatibility not tested. No representative cultivar available at Vineland.

sumed ' $\mathrm{S}_{4} \mathrm{~S}_{5}$ ' clone of 'Hedelfingen' was used to determine the possible sterility genes of the Vineland cultivars with 'Hedelfingen' as their maternal parent. Compatibility studies (Table 1) have shown that the ' $\mathrm{S}_{4} \mathrm{~S}_{5}$ ' clone of 'Hedelfingen' could not have contributed $\mathrm{S}_{1}$ and $\mathrm{S}_{2}$ or $\mathrm{S}_{3}$ alleles to 'Venus' $\left(\mathrm{S}_{1} \mathrm{~S}_{3}\right.$, 'Vogue' ( $\left.\mathrm{S}_{2} \mathrm{~S}_{3}\right)$, or 'Viva' $\left(\mathrm{S}_{2} \mathrm{~S}_{3}\right)$ (Tehrani, 1984; Tehrani and Dickson, 1973, 1974; Way, 1968). The Vineland clone of 'Hedelfingen', with 'two unknown alleles assigned to Group ' $O$ ' (Table 1), could have contributed any one of the said alleles to the mentioned cultivars. To show further that some other clones of 'Hedelfingen' belong to Group 'O', clone IR310-2, which was obtained from Michigan and maintained as a virus-tested clone at IR-2 Repository, Irrigated Agriculture Research and Extension Center, Presser, Wash. (Fridlund, 1980), was grown, fruited, and tested against the Vineland 'Hedelfingen'. IR310-2 was reciprocally incompatible with the Vineland clone, showing that both clones belong to Group 'O' with the same unknown alleles.

'Viscount' $\left(\mathrm{S}_{1} \mathrm{~S}_{4}\right)$ could have inherited the $\mathrm{S}_{4}$ allele from either the maternal 'Hedelfingen' $\left(\mathrm{S}_{4} \mathrm{~S}_{5}\right)$ or paternal 'Bing' $\left(\mathrm{S}_{3} \mathrm{~S}_{4}\right)$ parent. Since Vineland 'Hedelfingen' belongs to Group 'O': (Table 1), with unknown alleles, then the $\mathrm{S}_{4}$ allele possibly was inherited from the paternal 'Bing' $\left(\mathrm{S}_{3} \mathrm{~S}_{4}\right)$ parent. Therefore, the Vineland clone of 'Hedelfingen' with unknown S-alleles could be the female parent of 'Venus' (Dickson, 1956), 'Viva' (Tehrani and Dickson, 1973), 'Vogue' (Tehrani and Dickson, 1974), and 'Viscount' (Tehrani, 1984), as originally reported when these cultivars were named.

Recent and complementary studies at
Vineland have reconfirmed the findings of Way (1968) that 'Vic' could not have resulted from a 'Bing' $\left(\mathrm{S}_{3} \mathrm{~S}_{4}\right) \times \operatorname{Schmidt}\left(\mathrm{S}_{2} \mathrm{~S}_{5}\right)$ cross as reported by Dickson (1958). 'Vie' is compatible with the cultivars belonging to four possible allelic combinations that could have resulted from the above cross (Table 1). Therefore, the reported pedigree of 'Vie' is incorrect. 'Vie' belongs to Group 'O' rather than Group XIII $\left(\mathrm{S}_{2} \mathrm{~S}_{4}\right)$ reported by Knight (1969).

'Valera', a cultivar resulting from a 'Hedelfingen' (with assumed ' $\mathrm{S}_{4} \mathrm{~S}_{5}$ ' allelic combination) $\times$ Windsor $(\mathrm{S}, \mathrm{S}$, ) cross, was assigned to a new Group XIV ( $\mathrm{S}_{\mathrm{S}}$ ) by Matthews and reported by Way (1968). Since the Vineland clone of 'Hedelfingen' used in the above cross was later shown to belong to group ' $\mathrm{O}$ ', the' new allelic combination ' $\mathrm{S}_{1} \mathrm{~S}_{5}$ ' assigned to 'Valera' could not have resulted from the above cross. Incompatibility studies at Vineland (Table 1) have shown 'Valera' to belong to Group ' $\mathrm{O}$ '.

This study shows that the parentages of 'Venus', 'Viscount', 'Vogue', and 'Viva' appear correct as reported when these cultivars were named. The parentage of 'Vie' is incorrect and this cultivar belongs to Group 'O' rather than XIII, as previously reported. Also, the Vineland 'Hedelfingen' and 'Valera' both belong to Group ' $O$ ' rather than to Incompatibility Groups VII and XIV, previously assigned to these cultivars, respectively. The existence of the latter group could not be verified.

\section{Literature Cited}

Brown, A.G. 1955. Incompatibility. John Innes Inst. Annu. Rpt. for 1954. p. 7-8

Crane, M.B. and A.G. Brown. 1937. Incompat- ibility and sterility in the sweet cherry, Prunus avium L.J. Pomol. Hort. Sci. 15:86-116.

Crane, M.B. and A.G. Brown. 1955. Incompatibility and varietal confusion in cherries. Scientia Hort. 11:53-55.

Crane, M.B. and W.J.C. Lawrence. 1929. Genetical and cytological aspects of incompatibility and sterility in cultivated fruits. J. Pomol. Hort. Sci. 7:276-301.

Crane, M.B. and W.J.C. Lawrence. 1931. Sterility and incompatibility in diploid and polyploid fruits. J. Genet. 24:47-107.

DeVries, D.P. 1968. Compatibility of cherries in the Netherlands. Euphytica 17:207-215.

Dickson, G.H. 1948. Cherry breeding. Ont. Hort. Expt. Sta. \& Prod. Lab. Rpt. for 1947-48. p. 59-66.

Dickson, G.H. 1958. Vista, Venus and Vic sweet cherries. Ont. Hort. Expt. Sta. \& Prod. Lab. Rpt. for 1957-58. p. 43-44.

Fridlund, P.R. 1980. The IR2 program for obtaining virus free fruit trees. Plant Dis. 64:82r5830.

Knight, R.L. 1969. Abstract bibliography of plant breeding and genetics to 1965. Prunus. Eastern Press, London. p. 540-544.

Matthews, P. and P. Dow. 1966. Studies of sweet cherry. John Innes Inst. Annu. Rpt. for 1966. p. 30-31.

Matthews, P. and P. Dow. 1976. Cherry breeding-incompatibility groups. John Innes Inst. Annu. Rpt. for 1976. p. 21-22.

Tehrani, G. 1984. 'Viscount' sweet cherry. HortScience 19:451.

Tehrani, G. and G.H. Dickson. 1967. Vega and Valera sweet cherries. Hort. Res. Inst. Ont. Rpt. for 1967. p. 58

Tehrani, G. and G.H. Dickson. 1973. 'Viva' sweet cherry. HortScience 8:340.

Tehrani, G. and G.H. Dickson. 1974. 'Vogue' sweet cherry. HortScience 9:151.

Way, R.R. 1968. Pollen incompatibility groups of sweet cherry clones. Proc. Amer. Soc. Hort. Sci. 92:119-123. 